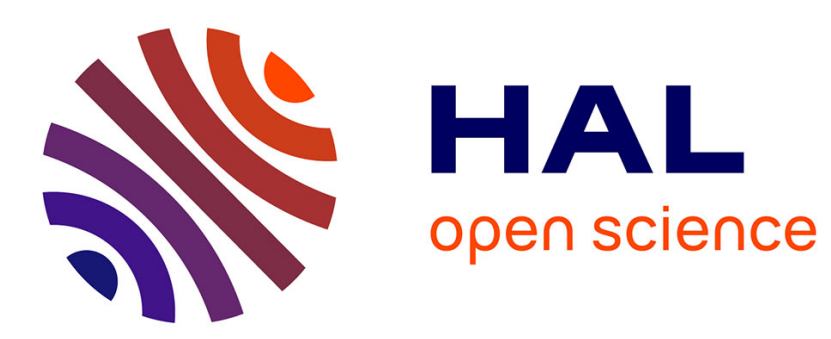

\title{
Soil roughness and overland flow
}

Gerard Govers, Ingrid Takken, Katharina Helming

\section{To cite this version:}

Gerard Govers, Ingrid Takken, Katharina Helming. Soil roughness and overland flow. Agronomie, 2000, 20 (2), pp.131-146. 10.1051/agro:2000114 . hal-00885998

\section{HAL Id: hal-00885998 https://hal.science/hal-00885998}

Submitted on 1 Jan 2000

HAL is a multi-disciplinary open access archive for the deposit and dissemination of scientific research documents, whether they are published or not. The documents may come from teaching and research institutions in France or abroad, or from public or private research centers.
L'archive ouverte pluridisciplinaire HAL, est destinée au dépôt et à la diffusion de documents scientifiques de niveau recherche, publiés ou non, émanant des établissements d'enseignement et de recherche français ou étrangers, des laboratoires publics ou privés. 


\title{
Review article
}

\section{Soil roughness and overland flow}

\author{
Gerard GOVERs $^{\mathrm{a}, \mathrm{c}^{*}}$, Ingrid TAKKEN ${ }^{\mathrm{a}}$ and Katharina HELMING ${ }^{\mathrm{b}}$ \\ ${ }^{\text {a }}$ Laboratory for Experimental Geomorphology, K.U.Leuven, Redingenstraat 16, 3000 Leuven, Belgium \\ ${ }^{\mathrm{b}}$ Centre for Agricultural Landscape and Landuse Research, Eberswalder Str. 84, 15374 Müncheberg, Germany \\ ${ }^{\mathrm{c}}$ Fund for Scientific Research, Flanders
}

(Received 15 March 1999; revised 16 November 1999; accepted 14 December 1999)

\begin{abstract}
Soil surface roughness affects surface depression storage, water infiltration, overland flow velocity as well as overland flow organisation. This paper attempts to give an overview of our knowledge of the effects of roughness on surface runoff and to indicate areas where further research is most needed. The relationship between soil surface roughness and depression storage is relatively well understood. On the other hand, few studies exist on the relationship between roughness and the infiltration characteristics of a tilled surface, although this may be more important. Insights, which have been developed over the past few years, may in the near future lead to a better prediction of the hydraulic resistance of interrill and concentrated overland flow. Recent studies have also provided important information on the effects of roughness on runoff patterns.
\end{abstract}

\section{soil roughness / depression storage / infiltration / hydraulic resistance / runoff pattern}

Résumé - Rugosité du sol et écoulement sur le terrain. La rugosité de la surface du sol affecte le stockage de l'eau dans les dépressions de la surface, son infiltration et la vitesse ainsi que l'organisation de l'écoulement sur le terrain. Cet article tente de donner une vue d'ensemble de nos connaissances actuelles sur les effets de la rugosité sur le ruissellement de surface et indique les domaines dans lesquels de nouvelles recherches sont les plus nécessaires. La relation entre la rugosité de la surface et le stockage de l'eau dans les dépressions est relativement bien connue. En revanche, il existe peu d'études sur la relation entre la rugosité d'une surface labourée et ses caractéristiques d'infiltration, bien que ce phénomène soit plus important. Les tentatives d'approche développées au cours des dernières années devraient conduire, dans un proche avenir, à une meilleure prédiction de la résistance hydraulique des zones de ruissellement diffus et concentré. Des études récentes ont fourni également des informations importantes sur les effets de la rugosité sur l'organisation spatiale de ruissellement.

Rugosité du sol / stockage dans les dépressions / infiltration / résistance hydraulique / organisation spatiale de ruissellement

Communicated by Gerard Guyot (Avignon, France)

*Correspondence and reprints

Gerard.Govers@geo.kuleuven.ac.be 


\section{Introduction}

The term soil roughness is used to describe disturbances or irregularities in the soil surface at a scale which is generally too small to be captured by a conventional topographic map or survey. Römkens and Wang [79] make a distinction between four types of roughness: (i) microrelief variations, which are due to individual grains or micro-aggregates, (ii) random roughness, which is related to soil clodiness, (iii) oriented roughness, which describes the systematic variations in topography due to farm implements and (iv) higher order roughness, representing elevation variations at the field, basin or landscape level. Studies on roughness and its effects on arable land usually concentrate on random and oriented roughness because these roughness types are far more important than microrelief variations while higher order roughness is adequately described by conventional topographical surveys.

Both oriented and random soil roughness affect various hydrologic and erosion processes on arable land. Soil roughness determines the storage of water on the soil surface and may indirectly influence its infiltration capacity. The velocity of overland flow is controlled by the hydraulic resistance of the soil surface. Soil roughness affects the organisation of the drainage pattern on the field and the catchment scale, which in turn may have important implications for the spatial distribution of sediment sources and sinks. Conversely, some of these processes affect surface roughness.

This paper attempts to give an overview of our knowledge with respect to the effects of random and oriented roughness on overland flow generation, hydraulics and organisation on arable land and to identify areas where further research may be needed. The first section, however, is devoted to roughness measurement and characterisation, which allows us to introduce and discuss some basic concepts that are used throughout the rest of the paper. In a final section runoff patterns are discussed, which are controlled by both oriented roughness and higher order roughness.

\section{Measurement of roughness}

Soil roughness is a measure of the variations in surface elevation. Over the last years a wide range of techniques has been used to measure surface elevations ranging from simple handheld rulers to more sophisticated non-contact devices. The most commonly used apparatus is a contact profile meter, consisting of a row of pins that can be lowered onto the surface. Nowadays, this system is often used in combination with photography [16].

Another simple and cheap method to measure surface roughness, is the chain method of Saleh $[80,81]$. This method is based on the principle that as a chain of given length, $L_{1}$, is placed across a surface, the horizontal distance covered, $\mathrm{L}_{2}$, will decrease as the roughness increases.

More recently, laser-scanning devices have been developed to measure surface roughness at high resolution e.g. [9, 46]. Only the laser beam makes contact with the soil thereby eliminating surface disturbance by physical probes. This method allows accurate measurements with grid spacings down to (sub)millimeter scales. Two types of laser scanners are reported in literature. Laser scanners that are based on triangulation project a laser beam vertical on the surface. The reflected laser spot is focussed onto a photosensitive recorder with a lens that is inclined by a small angle to the primary laser beam. The surface elevation is then defined by the position of the reflected laser spot on the recorder [46]. However, on a rough surface, the laser spot may hit the surface just behind a steep edge of a roughness element, so that the recorder cannot see it. Scanning the surface twice with the recorder in different positions can minimise this problem, but this requires a very accurate movement system. The other type of laser scanners is based on defect-of-focus techniques. Here the surface elevation is calculated from the size and light intensity of the reflected laser spot [9]. This system may give rise to problems on dark surfaces where the intensity of the reflected light is low and the method has shown to be sensitive to the colour of the surface (E. Kamphorst, INRA, personal communication). 
Another non-contact method to measure surface roughness is stereo photogrammetry $[47,95]$. This method is not yet commonly used for high-resolution measurements but may be more intensively applied in the future, as methods for automatic stereocorrelation become more reliable and userfriendly. Satellite radar data may allow to assess soil roughness over much larger surface areas: this technique is also in the experimental phase e.g. $[15,59,82]$.

It is important to realise that both the resolution and the surface area over which roughness is measured may have significant effects on the results obtained. Huang and Bradford [45] found that the estimated depression storage capacity of a simulated soil surface increased with increasing resolution. An increase of the sample area also led to an increase of estimated depression storage capacity.

\section{Roughness characterisation}

Elevation data can be used to calculate indices for surface roughness. In literature numerous indices to express (random) surface roughness are proposed. Generally these indices are calculated after the topographical data have been corrected for slope and, in some cases, tillage effects. Most commonly used are indices related to the variance of height measurements, like the Random Roughness index of Allmaras et al. [7]. Other well known indices are the MIF index [79], the Limiting Slope (LS) and Limiting Difference (LD) indices [52], the Tortuosity index [12], the roughness index of Saleh $[80,81]$ and the Fractal Dimension [10]. Also, spectral analysis has been used to analyse roughness e.g. [17, 100]. Huang and Bradford [45] and Bertuzzi et al. [10] give an overview of the different roughness indices used and their advantages and disadvantages are discussed. Zobeck and Onstad [102] have given a review of measured Random Roughness values for different tillage systems, previous crops and soil types.

Huang and Bradford [44] analysed roughness from a more theoretical viewpoint. They proposed that roughness can be described by combination of fractal Brownian and Markov-Gaussian models. They argued that roughness cannot be completely described by a single index, as a single index is never capable of quantifying both the variance (reflecting the absolute variations in height) and the correlation length (describing the distance over which spatial autocorrelation occurs). Most existing roughness indices indeed describe either the variance or the correlation length. Random Roughness and the Limiting Difference are strongly related to the variance, while the Fractal Dimension, the Tortuosity and the Limiting Slope are strongly controlled by the correlation length.

Despite the development of a range of roughness indices over the last decades, the Random Roughness index is still most widely used. Zobeck and Onstad [102] summarised Random Roughness values resulting from various tillage types (Tab. I).

Many authors have studied the effect of rainfall on Random Roughness (RR) and developed models to describe the decrease in RR as a function of amount of rainfall or rainfall kinetic energy [14, $21,49,55,67,68,78,87]$. These studies (except [55]) were summarised and compared by Zobeck and Onstad [102]. They used all these data to develop a general model to predict $R \mathrm{R}$ as a

Table I. Mean values of RR by tillage type [102].

\begin{tabular}{lccccccc}
\hline & Mould-board & Plow, disk & Plow, disk, harrow & Plow, disk, disk, harrow & Chisel & Rotary tillage & No-till \\
\hline Mean & 3.12 & 1.68 & 1.74 & 1.16 & 2.28 & 1.48 & 0.68 \\
C.V. & 36.8 & 25.5 & 29.2 & 14.1 & 28.9 & 20 & 28.2 \\
\hline
\end{tabular}


function of tillage operation and total amount of rainfall:

$$
\mathrm{RR} / \mathrm{RR}_{\mathrm{i}}=\mathrm{a} \exp (-\mathrm{b} \mathrm{P})
$$

$\mathrm{RR}=$ Random Roughness $(\mathrm{cm})$

$\mathrm{RR}_{\mathrm{i}}=$ initial Random Roughness (directly after tillage) $(\mathrm{cm})$

$\mathrm{P}=$ rainfall amount $(\mathrm{cm})$

$\mathrm{a}, \mathrm{b}=$ coefficients.

The coefficients were presented as constants, which results in a generalised function for all soils. However rainfall modifies RR at varying rates for different soils. Potter [74] estimated RR decay curves as a function of soil properties. He developed a model in the form of $\mathrm{RR}=\exp \left(-(\mathrm{P} / \mathrm{b})^{\mathrm{c}}\right)$ in which $c$ is a constant and $b$ is a function of organic matter content and clay percentage.

The widely accepted concept of decreasing roughness with increasing amount of rainfall may not always be appropriate. Huang and Bradford [45] measured surface roughness of a laboratory pan before the application of rainfall and after 63 and $155 \mathrm{~mm}$ of simulated rain. After $63 \mathrm{~mm}$ of rain the surface was crusted and surface roughness was decreased. However, an additional $92 \mathrm{~mm}$ of rain caused the development of microrills and the surface appeared to have a higher roughness. Crop growth may also lead to an increase in surface roughness. Figure 1 shows the evolution of the standard deviation of elevation measurements during the growing season of chicory (a root crop). Especially the roughness perpendicular to the direction of tillage increased between the last two measurements, due to the growth of the roots that push up the surrounding soil. The presence of rock fragments in the soil may have similar effects [93]. The formation of cracks and/or the activity of soil fauna may also cause deviations from the predicted exponential decline of soil roughness with rainfall amount [85].

Bertuzzi et al. [10] described six roughness indices and discussed their usefulness for describing soil surface change by rainfall. They found that all indices captured the decrease of roughness with cumulative rainfall, despite the fact that the correlation between the various roughness coefficients was sometimes rather low. For a given surface, the

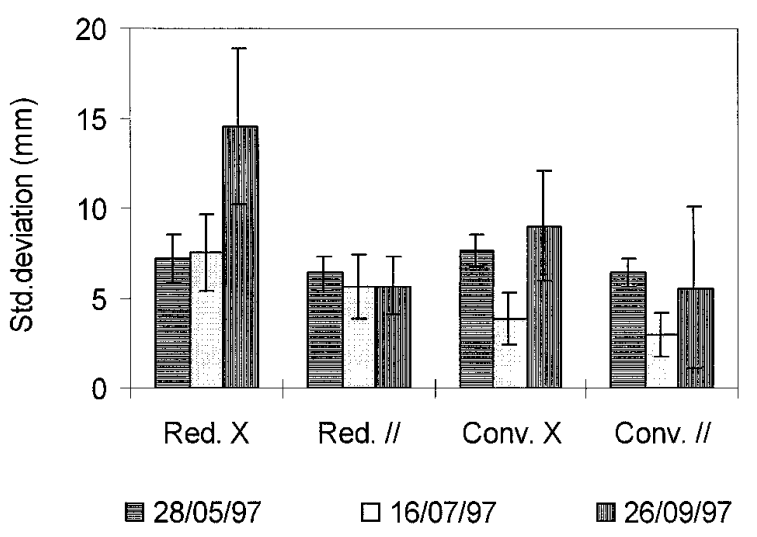

Figure 1. Surface roughness expressed as standard deviation of height measurements along $1 \mathrm{~m}$ long profiles with $1 \mathrm{~cm}$ spacing. (Red. $=$ reduced tillage, Conv. $=$ conventional tillage, $\mathrm{X}=$ measurements made perpendicular to sowing lines, $/ /=$ measurements made parallel to sowing lines.)

variability in roughness index values was lowest for the Tortuosity index [12] and highest for the MIF-index [79].

\section{Depression storage}

Surface roughness data have been used to calculate surface storage capacity, i.e. the maximum equivalent water depth that can be stored on the soil surface. The studies of Mitchell and Jones [57], Moore and Larson [61] and Onstad [66] were based on elevation measurements obtained on a relatively coarse grid. The more detailed data of surface roughness obtained by laser scanning techniques allow examining water depths and volumes in a spatially varying manner [37,44]. This is important as the resulting values for depression storage are dependent on the grid spacing [44].

Various algorithms have been used to calculate depression storage. In general, these algorithms try to determine the amount of water needed to fill all the depressions present on the surface up to their "pour point", i.e. the water level at the moment that they start to overflow. However, the results of the calculations depend on the algorithm used to 
delineate depressions as well as on the assumptions made with respect to open depressions, i.e. depressions connected to the plot border.

Onstad [66] presented a thorough study of the relationship between depression storage and Random Roughness. He found that variations in depression storage could be well predicted from variations in Random Roughness and slope gradient:

$$
\mathrm{DS}=0.112 \cdot \mathrm{RR}+0.031 \cdot \mathrm{RR}^{2}-0.012 \cdot \mathrm{RR} \cdot \mathrm{S}
$$

where:

$\mathrm{DS}=$ the maximum depression storage $(\mathrm{cm})$

$\mathrm{RR}=$ the Random Roughness index according to Allmaras et al. [7] (cm)

$\mathrm{S}=$ the slope gradient (percent)

Depression storage can be quite important: Moore and Larson [61] report values exceeding $20 \mathrm{~mm}$ for a freshly mouldboard ploughed soil surface with zero slope. However, values are in most cases much lower. If a seedbed is prepared using a harrow or rotary tillage, Random Roughness is always below $20 \mathrm{~mm}$ [102], which, according to the model of Onstad [66], results in depression storage values below $3 \mathrm{~mm}$ on a zero slope. This value decreases even further for sloping surfaces $[44,66]$. Furthermore, values for depression storage should be correctly interpreted: the work by Onstad [66] shows that runoff will start well before all depressions are filled to their maximum. On a $4 \%$ slope with a Random Roughness of $16 \mathrm{~mm}$, the maximum depression storage is estimated as ca 2 $\mathrm{mm}$. However, ca $6 \mathrm{~mm}$ of rainfall is needed to fill this storage completely, resulting in a runoff excess of ca. $4 \mathrm{~mm}$.

Hansen et al. [38] studied the efficiency of various roughness indices for the prediction of depression storage. When comparing existing indices, the best results were obtained with a combination of the Limiting Difference index and slope: combinations of Random Roughness and slope also gave reasonable results. They also proposed a new roughness index (MUD: Mean Upslope Depressions) which performed significantly better than the existing roughness indices for their dataset. Another interesting result from their study concerns the sample magnitude needed to estimate depression storage reliably. The accuracy obtained is a function of both the number of slope profiles sampled as well as their length. They found that, in general, roughness measurements along 10 slope profiles over a length of $120 \mathrm{~cm}$ resulted in an accurate estimation of depression storage.

\section{Infiltration}

Soil roughness does not only affect the runoff amount through depression storage, but may also affect the volume and rate of infiltration. Several experimental studies have shown an effect of surface roughness on infiltration rate. On rough surfaces the amount (or kinetic energy) of rainfall required to initiate runoff is higher e.g. [26, 40, $42,58]$. This is not only due to larger depression storage, but also to the fact that the process of surface sealing is affected by surface roughness. It was observed that surface sealing was reduced on rough surfaces. This could be explained by the fact that rough surfaces have a larger surface area, which means that the impact force of raindrops is spread over a larger area. In addition, the local slope of the surface will be higher on rough surfaces, which leads to a lower impact force in the direction normal to the soil surface [40, 42, 53, 58]. Brakensiek and Rawls [13] developed a procedure to estimate Green and Ampt infiltration equation parameters for tilled agricultural soils, including the effect of roughness on surface crusting. In their model, which was later incorporated in WEPP [76], the decrease of effective hydraulic conductivity with rainfall energy is assumed to be dependent on random roughness as the latter affects the rainfall crusting energy [53].

Results are different with respect to final infiltration rates. The final infiltration rates reported by Moldenhauer [58] after $90 \mathrm{~min}$ of rainfall at $67 \mathrm{~mm} / \mathrm{h}$ do not systematically vary with initial clod size distribution, except for the case where all clods < $30 \mathrm{~mm}$ were removed: in this case, higher final infiltration rates were measured. Falayi and Bouma [26] did not find a significant effect of initial soil roughness on final infiltration rates 
measured in the field after ca. $2 \mathrm{~h}$ of simulated rainfall at $85 \mathrm{~mm} / \mathrm{h}$. Helming [42] noted that the difference in infiltration rates between smooth, medium rough and rough surfaces diminished continuously with rainfall. Final infiltration rates after 180 min of rainfall at varying intensities were almost equal. Thus, the initial roughness of the surface appears to have a strong control on runoff and infiltration during the first phases of the crusting process. Infiltration rates of surfaces with a fully developed crust are more or less independent of initial soil roughness.

It has been known for quite some time that the infiltration characteristics of a soil surface are very variable, so that a large number of samples are required for an adequate characterisation of its hydraulic properties e.g. [94]. Such variability is typical for both natural and tilled surfaces, although the controlling factors may be different. Variations in infiltration capacity on natural surfaces can occur at various scales due to variations in soil thickness, vegetation, etc. e.g. [8, 23, 99]. If variations in infiltration capacity are important enough, this automatically implies that the average infiltration capacity of the soil surface under rainfall will increase with rainfall intensity $[8,23$, 39, 71]. Dunne et al. [23] showed that, in some cases, part of this variation could be related to variations in mictotopography whereby the soil mounds below grass tussocks has a much higher infiltration capacity than the lower-lying non-vegetated areas. Consequently, an increase of surface water depth led to a strong increase in infiltration as increasingly more permeable areas of the soil surface became submerged.

Microtopography may also affect infiltration on cultivated soils. Falayi and Bouma [26] observed differences in crust morphology and hydraulic conductance due to surface roughness. The hydraulic conductance on top of soil clods was larger than in the valleys between soil clods. Valentin [90] also noted that a clear distinction could be made between the crust formed on positive roughness elements and the crust formed in depressions: in the depressions, a thick, depositional crust was found, while the mounds were covered by a much thinner, structural crust. Systematic experimental studies of the effects of these spatial variations on the overall infiltration characteristics of a crusted surface formed on a tilled soil were lacking until the recent work by Fox et al. [29, 30]. Their studies clearly demonstrated that the observed spatial variability in crust properties (related to soil roughness) leads to an increase of the apparent infiltration capacity of the surface with increasing ponding depth. The effect of water depth on infiltration appeared to be far more important for an well-aggregated soil than for a strongly crusting soil. The observed variations are such that they may have a very significant influence on the total runoff production of a field: Fox et al. [30] measured a 4-fold increase in infiltration capacity of a crusted silty loam when the water depth was increased from c. 1.5 to c. $2.5 \mathrm{~mm}$.

At present, too little experimental information is available to predict in detail the effects of soil roughness on runoff generation. However, the available evidence suggests that soil roughness effects on runoff generation are as much due to its effect on infiltration capacity as to its effect on depression storage. This is clearly an area where more scientific work is needed.

\section{Flow hydraulics}

\subsection{Interrill flow}

The hydraulic resistance of a surface can be determined using various methods. Most commonly, flow depths and/or velocities are recorded for a range of discharges over the surface: discharge may be supplied either by trickle flow at the upslope end of the plot e.g. [5] or by rainfall e.g. [96]. However, the measurement of flow depth and velocity on rough surfaces is difficult and relatively large measurement errors can be expected. In Figure 2 two different methods to measure flow velocity on a rough interrill surface are compared. The measurements were made on a flume $(2.3 \mathrm{~m}$ long $0.6 \mathrm{~m}$ wide) at various discharges supplied at the top of the flume on a fixed soil surface. The first method was a dye tracing method. The leading 


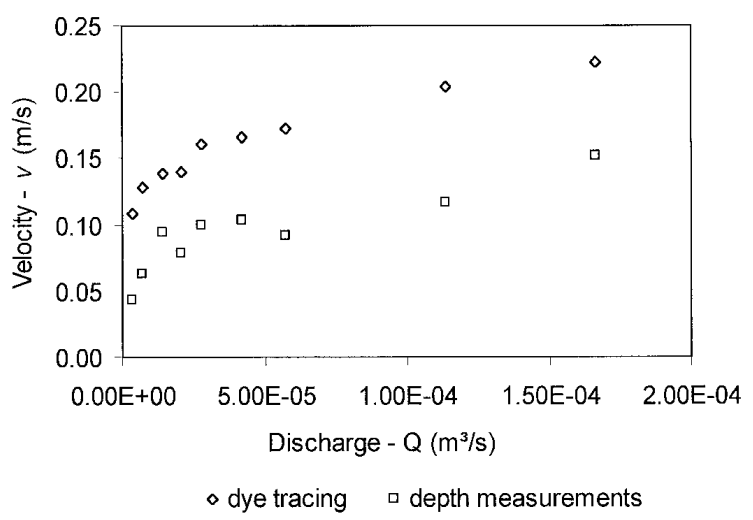

Figure 2. Measured flow velocities by two different measurement methods (ea. dye tracing and the measurement of flow width and depth) versus discharge.

edge of the dye cloud was measured for different flow lines across the test area. The second method was the calculation of average flow velocity from measurements of flow depths, widths and discharge. Depth and width measurements were made along three transects perpendicular to the flow direction. The width of each flow line was measured and depth was measured with a callipers on a $1 \mathrm{~cm}$ interval along the transect. The flow velocities that result from depth measurements are lower than the velocities measured by dye tracing. This can be explained on the one hand by an overestimation of the flow velocity by the dye tracing method. Firstly, dye tracing of the leading edge is generally considered as a measure of surface flow velocity. In literature several coefficients have been proposed to correct these values to obtain average flow velocity e.g. [24, 72]. Li et al. [51] propose a set of correction equations which allow the calculation of the mean flow velocity from tracer measurements. Secondly, if the flow is spatially variable, only the areas where the flow is relatively fast will be sampled by dye tracing [2]. On the other hand, depth measurements can result in an underestimation of flow velocities, because areas of standing or hardly flowing water are also taken into account.

Alternatively, roughness parameters are derived from the falling limb of the hydrograph using best-fit techniques e.g. [25, 96]. This technique is based on two assumptions. Firstly, it is assumed that a hydraulic resistance equation such as the Darcy-Weisbach or the Manning equation can describe the flow on the surface. Secondly, it is assumed that the flow is spatially uniform. While fitting the hydrograph, a constant value for the roughness coefficient will be calculated, which is then used to calculate other flow parameters (velocity, depth). However, these roughness coefficients are not independent on flow rate. On rough surfaces or surfaces with vegetation cover Manning's n varies with flow depth [89]. Also, assumptions need to be made on infiltration rate, which is generally taken constant and uniform over the plot. Parsons et al. [70] argue that the direct measurement of depth is a more reliable method to define the friction factor than the hydrograph method.

Besides the differences that may result from different measurement methods, the method of water application during experiments may also have an effect on the measured hydraulic resistance. Parsons et al. [70] compared two different experimental setups and showed that friction factors measured using artificial rainfall may be an order of magnitude higher than those obtained using trickle-induced runoff. It is well known that drop impact leads to an increase of flow resistance e.g. [83]. However, this increase is only $20 \%$ for laminar flow on low slopes and decreases with increasing discharge and slope [83]. The observed difference in friction factor between trickle flow and rainfall simulation experiments is often an order of magnitude. The additional increase in friction factor is explained by a difference in flow paths formed during the different experiments. When trickle inflow is used some parts of the plot remain outside the area of flow, while rainfall-induced runoff is distributed over the whole plot leading to lower flow depths and velocities. Thus, the microtopography does not only affect the hydraulic resistance due to flow obstruction but it also affects the flow pattern. On a rough surface flow will concentrate between the clods, routing the runoff within several flow paths on a small portion of the surface [41]. This was also found by Parsons et al. [69], 
who described a downslope decrease in hydraulic resistance due to flow concentration. Therefore, trickle flow experiments will give good information when a surface is considered to receive a relatively large amount of overland flow from upslope areas. If, on the other hand, the hydraulic resistance has to be estimated for conditions where the contribution of overland flow from upslope is relatively minor, then the use of rainfall simulation is a necessity.

The three most widely used equations to predict velocity and depth of flow are the DarcyWeisbach, Chezy and Manning equations. These equations require the value of a friction factor or roughness coefficient as input (Darcy-Weisbach f, Chezy $\mathrm{C}$ and Manning's n respectively). Values for Manning's $\mathrm{n}$ for many different surfaces can be found in tabular format e.g. [25]. It is then assumed that Manning's $n$ is independent of flow rate. Gilley and Finkner [31] presented regression equation relating Manning's $n$ and the Darcy-Weisbach $f$ to the flow Reynolds number and the Random Roughness Index. Several other field and laboratory experiments were carried out to study the relationship between Darcy-Weisbach f, the flow Reynolds number and other controlling variables $[3-5,22,33,77,83,84]$. In these studies the form of the f-Re relationship varies from convex-upward to negatively sloping. These shapes have been explained in terms of the progressive inundation of the roughness elements. If the flow depth is smaller than the height of the roughness elements, progressive inundation results in an increase in the wetted upstream-projected area and therefore in increasing hydraulic resistance. Where the flow overtops the roughness elements, progressive increase in depth of flow over the already inundated element results in a decreasing resistance. Those processes operate simultaneously and whether the f-Re curve has a positive or a negative slope depends on which process is dominating. This in turn will depend on the configuration of the bed and the discharge level [3]. f-Re relations are of little value as models for predicting flow resistance at locations other than those where they were developed for, because each location has its own unique relation, which is a function of the surface proper- ties at that location [5]. No single f-Re relationship describes the hydraulics of an entire slope and the relationship cannot be extrapolated to large areas [60].

Until recently, attempts to obtain a more general relationship were based on regression analysis: empirical equations were developed to calculate the friction factor from data on soil cover, soil roughness and flow Reynolds number e.g. [5, 96]. Such attempts are not always very successful. Furthermore, such equations may have a limited applicability outside of the areas for which they were developed as the parameters present in such equations are dependent on the site characteristics [5].

Another approach is based on the assumption that the overall Darcy-Weisbach friction factor of a rough surface may be calculated as the sum of a number of subfactors, each describing the contribution of a certain component of the surface (stone cover, vegetation elements...) to the total roughness. However, it is far from clear whether the effects of various components of roughness may be linearly combined, although in some cases such a combination is indeed possible e.g. [33, 75].

In a recent study, Lawrence [50] proposes a fundamentally different approach. Based on fundamental equations describing the velocity profile of thin flows, she developed a model whereby the frictional resistance of an interrill surface is no longer predicted using the flow Reynolds number, but the inundation ratio, i.e. the ratio between the depth of flow and the size of the roughness elements, as well as the concentration of roughness elements. At partial inundation the flow resistance increases with depth and percentage cover. At marginal inundation frictional resistance decreases very rapidly with increasing depth of flow. Wellinundated flows exhibit a decrease in frictional resistance with increasing depth, but much more gradual than that observed during marginal inundation. She also showed that the new model is capable of predicting the trends present in the experimental data obtained by various authors. Further research is needed to investigate whether the model proposed by Lawrence indeed allows a 
more general characterisation of the hydraulic resistance of interrill surfaces as compared to earlier attempts.

The practical application of Lawrence's model in soil erosion models may be complicated. Firstly flow depth is required to calculate the inundation ratio, which implies that the friction coefficient can only be calculated iteratively when flow depth is to be predicted. Secondly, it is not clear how the roughness length should be defined. Lawrence [50] used the $\mathrm{D}_{50}$ of the roughness elements to calculate the roughness length. For soil material without macro roughness elements $D_{50}$ was defined from the particle size distribution of the soil material. If the soil was covered with larger roughness elements $\mathrm{D}_{50}$ of these roughness elements was used (in combination with the fractional cover). It is difficult to transfer these concepts to tilled surfaces because these surfaces consist of a range of particle sizes, which makes it is difficult to express the roughness in a single measure. The fraction of the surface covered by 'larger' roughness elements is also hard to define in this case.

The approaches described above all attempt to characterise a topographically rough surface by a single hydraulic resistance coefficient, which may, for a given surface, vary in function of flow depth. It is also possible to model the effect of soil roughness on flow dynamics explicitly, using a twodimensional solution of the Saint-Venant equations [101]. Zhang and Cundy [101] studied the effects of spatial variations in hydraulic resistance, surface microtopography and infiltration rates on the predicted outflow hydrograph. However, a comparison with experimental data has not been carried out.

In most experimental and modelling studies on hydraulic resistance, which have been carried out this far, it is implicitly assumed that the distribution of cover and/or roughness elements over the surface is random. This assumption does not hold for agricultural surfaces, where both roughness and cover are spatially structured. Only limited information is available on the effect of roughness and/or cover structure: Gilley and Kottwitz [32] carried out a series of experiments whereby the effect of row orientation with respect to the flow direction was considered and concluded that the hydraulic resistance was generally less when the vegetation rows were parallel to the flow.

\subsection{Concentrated flow}

Due to tillage practices, height differences along field boundaries, soil erosion etc., runoff often becomes concentrated in non-permanent channels, like rills and ephemeral gullies. The width of nonpermanent channels can vary between a few $\mathrm{cm}$ (e.g. rills) and several $\mathrm{m}$, while their catchment area varies between several $\mathrm{m}^{2}$ and tens of hectares. The non-permanent channel network is in many cases the major source of sediment transported off agricultural land e.g. [11, 35, 73, 91].

Some models do not consider the non-permanent channel network and assume an aggregated value of the hydraulic resistance to be representative for the whole surface (e.g. LISEM, [18]). In other models, the Manning or the Darcy-Weisbach equation is used to route flow through the non-permanent channels e.g. [63]. Recent experimental research has shown that flow in non-permanent channels is not well described by this approach. Govers [34] found that equilibrium flow velocities in rills are independent of the slope gradient, which is not in agreement with predictions from the Manning or the Darcy-Weisbach equations. A compilation of literature data showed that flow velocities in rills in loose, homogeneous soils can well be predicted from discharge alone, using the following power relationship:

$$
v=3.52 Q^{0.294}\left(\mathrm{r}^{2}=0.73, \mathrm{n}=408\right)
$$

where $v=$ the average flow velocity $\left(\mathrm{m} \cdot \mathrm{s}^{-1}\right)$ $Q=$ the rill discharge $\left(\mathrm{m}^{3} \cdot \mathrm{s}^{-1}\right)$.

The absence of a slope effect on flow velocities in rills was also reported by Nearing et al. [64] and Takken et al. [88]. However, available data also suggest that equation (3) is not universally valid.

The effect of rock fragments on rill flow velocities was investigated experimentally in the flume, which was also used by Govers [56]. However, only the lower $2 \mathrm{~m}$ of the flume were used. Before each experiment the flume was emptied to a depth 
of ca. $0.25 \mathrm{~m}$ and refilled with a loosely packed mixture of a silty loam soil and rock fragments varying in size between 17 and $27 \mathrm{~mm}$. The flume was then set to the desired slope and runoff was applied with a pre-set discharge. Velocity was measured by dye tracing, using the technique proposed by Govers [34]. Figure 3 shows that the average flow velocity in the rills is indeed affected by the presence of rock fragments. However, the rock fragment concentration does not have a significant effect on flow velocity. When non-erodible rock fragments are present, average flow velocity can be predicted by the following equation:

$$
v=4.19 \mathrm{Q}^{0.344}\left(\mathrm{r}^{2}=0.93, \mathrm{n}=28\right) .
$$

Other limitations of equation (3) were identified by Takken et al. [88]. Equation (3) appears to be valid only when the flow is capable of freely adjusting the bed geometry. If non-erodible vegetation elements are present, flow velocities can be much lower than predicted. However, if the competence of the flow is sufficient to erode and transport the roughness elements, velocities are accurately predicted by equation (3). If bed erosion is severely restricted due to soil consolidation, the velocities may both be higher or lower than predicted, depending on the initial soil roughness and slope.

Data obtained on fixed beds also suggest that the interaction between flow hydraulics and bed geometry is crucial: experiments on rills with a fixed bed often reveal a significant slope effect on velocity $[6,28]$. In such experiments the flow cannot adjust its bed: as a consequence, the data obtained are irrelevant to the natural situation.

Although a general model predicting the hydraulic resistance of rills does not yet exist, some implications of the findings reported above are clear. If free bed adjustment is possible, flow velocities are independent of slope and/or soil characteristics. It follows from this that, if the Manning equation is used to route flow through rills and a constant roughness coefficient is assumed, velocities will be overpredicted on steep slopes and underpredicted on low slopes. This will not only affect predictions of both timing and amount of runoff but also of erosion rates over the slope. The adaptation of the hydraulic roughness to

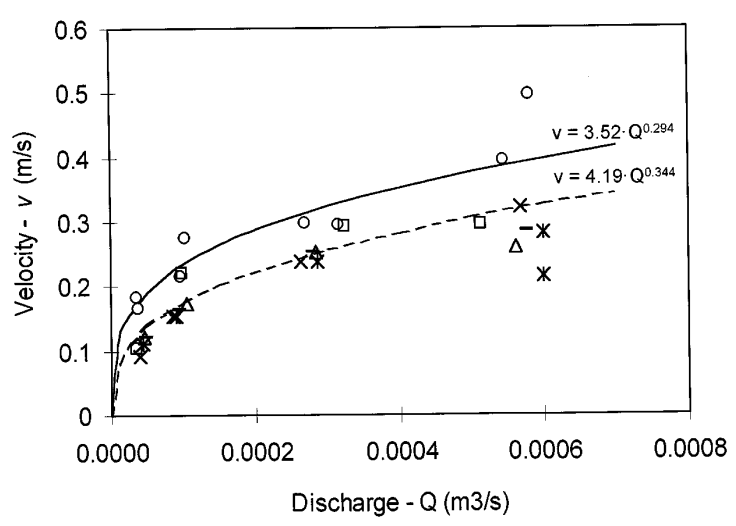

Stone content (\%): $\circ 0.0 \square 7.55 \Delta 10.0 \times 15.55 * 20.0-31.1$

Figure 3. Flow velocities in rills versus discharge for surfaces with varying stone content, including the equations of Govers ( $\longrightarrow$ ) and Mertens (- -- ): Govers' equation is valid when no non-erodible roughness elements are present.

the flow conditions can occur relatively rapidly. Thus information on the topographic roughness of an agricultural soil surface before an event will often have only limited relevance for concentrated flow hydraulics. Present-day models do not allow taking this rapid change in hydraulic conditions into account, as a fixed roughness coefficient is assumed to be associated with a given surface.

Experimental research on the hydraulics of concentrated flow in non-permanent, self-forming channels is necessary to explain the findings described above and should ultimately result in a better model for the prediction of the hydraulic resistance in rills.

\section{Runoff patterns}

The pathways followed by surface runoff on arable land are determined by topography as well as macroscale roughness of various types (tillage marks, roads, field borders...). Ideally, a deterministic model should be capable of predicting the location and geometry of non-permanent concentrated flow channels. Recent research shows that it 
may indeed be possible to predict accurately the location of ephemeral gullies of a certain size from information on topography and tillage direction e.g. $[19,20,54,62,92]$. However, this is not feasible for rills in the context of a robust, widely applicable hydrology/erosion model, as very detailed information on topography and roughness would be required. Even a digital elevation model with a $5 \mathrm{~m}$ horizontal resolution and a vertical precision of a few centimeters does not provide the necessary information to predict the starting point of individual rills [20]. On the other hand, the statistical characteristics of rill networks can be determined from detailed studies of runoff organisation on small plots or flumes [43, 65, 98]. These studies show that the bifurcation and length ratios as well as the fractal characteristics of equilibrium networks are similar to those of river networks. Such statistical information may then be used to simulate a rill drainage network that can subsequently be used as input for a soil erosion model [98]. However, this approach does not allow to take into account the dynamic evolution of a rill network observed in experiments [43]. Favis-Mortlock [27] developed RILLGROW, a dynamic model of rill initiation and network formation that, in principle, should be capable of simulating such temporal changes.

The studies described above were limited to plane surfaces having only random roughness (no oriented roughness). However, rill network organisation is also controlled by oriented roughness and/or two-dimensional variations in topography (planform curvature). Desmet and Govers [20] and Souchere et al. [86] proposed empirical models to predict the effects of topography and tillage marks on runoff organisation. Studies on the effect of oriented roughness and planform curvature on rill network characteristics and evolution have not been carried out yet.

\section{Conclusions}

Our knowledge of the effect of soil roughness on hydrological and erosion processes is far from complete. Soil roughness has been investigated for more than 30 years. Major progress has been made concerning roughness measurement, mainly due to the introduction of laser scanners. Also, various methods and indices to characterise soil roughness have been proposed. Only in a few studies, an attempt has been made to compare the performance of various roughness indices. Considering the observations of Huang and Bradford [44] on the inadequate description of roughness by a single index, it may seem surprising that single roughness indices have been used successfully in many studies. This indicates that, although a single index may not be sufficient to give a complete description of roughness, it may often be sufficient to predict the effects of roughness on the process of interest, e.g. depression storage.

There are relatively accurate and robust techniques to estimate the effect of soil random roughness on depression storage. On the other hand, limited data are available with respect to the effect of roughness on infiltration. The available evidence suggests that infiltration is strongly dependent on soil roughness during the initial phases of crust development, while the final infiltration rates of fully crusted surfaces are not. The infiltration characteristics of a rough, tilled surface can vary significantly with water depth and thus with rainfall intensity and/or runoff length. More experimental work is needed to investigate under which circumstances these variations are important enough to invalidate the assumption of a fixed hydraulic conductivity for a given soil in a given condition.

Various studies in the field and the laboratory have concentrated on hydraulic resistance. Multiple regression models for the prediction of interrill hydraulic resistance have important limitations. A more conceptual approach as has recently been proposed by Lawrence [50] may be more successful, but its application to tilled surfaces is not straightforward. There is also a need for more experimental data on interrill hydraulic resistance, in order to identify effects of vegetation and roughness structure as well as to evaluate deterministic (two-dimensional) models of interrill overland flow. 
Experiments on the hydraulic resistance of concentrated flow channels have led to the conclusion that in many cases, the velocity of the flow is independent of slope. This is explained by the feedback between flow and bed characteristics when free bed adjustment is possible. At present, a general model predicting the hydraulics of rill and ephemeral gully flow is not available, also because data on the effects of various controls on rill and ephemeral gully flow are still limited.

The spatial organisation of runoff is affected by random roughness, oriented roughness as well as topography. The location (and possibly the geometry) of large runoff collectors (ephemeral gullies) may be predicted deterministically. However, the spatial organisation of rill and interrill runoff networks has to be represented stochastically. Some information on rill and interrill drainage network development is already available, but the available experimental and field data are insufficient to develop the proposed modelling concepts further.

More scientific work in the areas identified above will allow to eliminate structural errors from models describing surface hydrological and erosion processes. Although this is a basic step towards better models of surface flow, it should be kept in mind that there are other, important problems associated with the use of deterministic hydrology/erosion models. An excellent general overview of the issues involved with respect to hydrological models is provided by Grayson and Moore [36]. In general, the uncertainty associated with estimation of parameter values for surface areas larger than the typical scale of measurement is such that accurate predictions on an event basis, may be unachievable. However, deterministic models have a continuing role as a tool to increase our understanding of hydrological and erosion processes and to investigate possible effects of changes in land use and agricultural practices.

Acknowledgements: Part of the work reported in this paper was financially supported by the Commission of the European Union under the FAIR program (FAIR CT95-0458).

\section{References}

[1] Abrahams A.D., Parsons A.J., Hydraulics of interrill overland flow on stone-covered desert surface, Catena 23 (1994) 111-140.

[2] Abrahams A.D., Parsons A.J., Luk S.H., Field measurements of the velocity of overland flow using dye tracing, Earth Surf. Processes and Landforms 11 (1986) 653-657.

[3] Abrahams A.D., Parsons A.J., Luk S.H., Resistance to overland flow on desert hillslopes, J. Hydrol. 88 (1986) 343-363.

[4] Abrahams A.D., Parsons A.J., Luk S.H., Field experiments on resistance to overland flow on desert hillslopes, in: Proc. Jerusalem Workshop, March-April 1987, IAHS Publ. no. 189, 1990, pp. 1-18.

[5] Abrahams A.D., Parsons A.J., Wainwright J., Resistance to flow on semiarid grassland and shrubland hillslopes, Walnut Gulch, southern Arizona., J. Hydrol. 156 (1994) 343-363.

[6] Abrahams A.D., Li G., Parsons A.J., Rill hydraulics on a semi-arid hillslope, southern Arizona, Earth Surf. Processes and Landforms 21 (1996) 35-47.

[7] Allmaras R.R., Burwell R.E., Larson W.E., Holt R.F., Total porosity and random roughness of the interrow zone as influenced by tillage, in: USDA Conserv., Res. Rep no. 7. U.S.Gov. Print. Office, Washington DC. 1966, pp. 1-22.

[8] Bergkamp G., A hierarchical view of the interactions of runoff and infiltration with vegetation and microtopography in semiarid shrublands, Catena 33 (1998) 201-220.

[9] Bertuzzi P., Stengel P., Measuring effects of tillage implements on soil surface geometry with a laser reliefmeter, Proc. 11th Int. Soil and Tillage Res. Organization, Edinburgh, July 1988, Vol. 1, pp. 7-12.

[10] Bertuzzi P., Rauws G., Courault D., Testing roughness indices to estimate soil surface roughness changes due to simulated rainfall, Soil Tillage Res. 17 (1990) 87-99.

[11] Boardman J., Hazelden J., Examples of erosion on brickearth soils in east Kent, Soil Use Manage. 2 (1986) 105-108.

[12] Boiffin J., La dégradation structurale des couches superficielles sous l'action des pluies, Thèse de Docteur-Ingénieur, Inst. Nat. Agron., Paris, 1984, pp. 128. 
[13] Brakensiek D., Rawls W.J., Agricultural management effects on soil water processes, Part II: Green and Ampt parameters for crusting soils, Trans. ASAE 26 (1983) 1753-1757.

[14] Burwell R.E., Larson W.E., Infiltration as influenced by tillage-induced random roughness and pore space, Soil Sci. Soc. Am. J. 33 (1969) 449-452.

[15] Courault J.D., Bertuzzi P., Girard M.C., Monitoring surface changes of bare soils due to slaking using spectral measurements, Soil Sci. Soc. Am. J. 57 (1993) 1595-1601.

[16] Cremers N.H.D.T, Van Dijk P.M., De Roo A.P.J., Verzandvoort M.A., Spatial and temporal variability of soil surface roughness and the application in hydrological and soil erosion modeling, Hydrol. Process. 10 (1996) 1035-1047.

[17] Currence H.D., Lovely W.G., The analysis of soil surface roughness, Trans. ASAE 13 (1970) 710-714.

[18] De Roo A.P.J., Wesseling C.G., Ritsema C.J., LISEM: a single event physically based hydrological and soil erosion model for drainage basins: theory, input and output, Hydrol. Process. 10 (1996) 1107-1117.

[19] Desmet P.J.J., Govers G., Comparison of routing algorithms for digital elevation models and their implications for predicting ephemeral gullies, Int. J. Geograph. Info. Systems 10 (1996) 311-331.

[20] Desmet P.J.J., Govers G., Two-dimensional modelling of the within-field variation in rill and gully geometry and location related to topography, Catena 29 (1997) 283-306.

[21] Dexter A.R., Effect of rainfall on the surface microrelief of tilled soil, J. Terramech. 14 (1997) 11-22.

[22] Dunne T., Dietrich W.E., Experimental study of Horton overland flow on tropical hillslopes, 2. Hydraulic characteristics and hillslope hydrographs, Z. Geomorphol. Suppl. 35 (1980) 60-80.

[23] Dunne T., Zhang W., Aubrey D., Effects of rainfall, vegetation and microtopography on infiltration and runoff, Water Resour. Res. 27 (1991) 2271-2285.

[24] Emmett W.W., The hydraulics of overland flow on hillslopes, U.S. Geological Survey Professional Paper 662-A, 1970, 68 pp.

[25] Engman E.T., Roughness coefficients for routing surface runoff, J. of Irrig. Drainage Eng. 112 (1986) 39-53.

[26] Falayi O., Bouma J., Relationships between the hydraulic conductance of surface crusts and soil man- agement in a Typic Hapludalf, Soil Sci. Soc. Am. Proc. 39 (1975) 957-677.

[27] Favis-Mortlock D., A self-organizing dynamic systems approach to the simulation of rill initiation and development on hillslopes, Computers Geosci. 24 (1998) 353-372.

[28] Foster G.R., Huggins L.F., Meyer L.D., A laboratory study of rill hydraulics I. Velocity relationships, Trans. ASAE 27 (1984) 790-796.

[29] Fox D.M., Le Bissonais Y., Bruand A., The effect of ponding depth on infiltration in a crusted surface depression, Catena 32 (1998) 87-100.

[30] Fox D.M., Le Bissonnais Y., Quétin P., The implications of spatial variability in surface seal hydraulic resistance for infiltration in a mound and depression topography, Catena 32 (1998) 101-114.

[31] Gilley J.E., Finkner S.C., Hydraulic roughness coefficients as affected by random roughness, Trans. ASAE 34 (1991) 897-903.

[32] Gilley J.E., Kottwitz E.R., Darcy-Weisbach roughness coefficients for selected crops, Trans. ASAE 37 (1993) 467-471.

[33] Gilley J.E., Flanagan D., Kottwitz E.R., Weltz M.A., Darcy-Weisbach roughness coefficients for overland flow, in: Parsons A., Abrahams A.D. (Eds.), Overland Flow: Hydraulics and Erosion Mechanics, UCL Press, London, 1992, pp. 25-52.

[34] Govers G., Relationship between discharge, velocity and flow area for rills eroding loose, non-layered materials, Earth Surf. Processes and Landforms 17 (1992) 515-528.

[35] Govers G., Poesen J., Assessment of the interrill and rill contributions to total soil loss from an upland field plot, Geomorph. 1 (1988) 343-354.

[36] Grayson R.B., Moore I.D., Physically based hydrologic modelling 2 . Is the concept realistic?, Water Resour. Res. 26 (1992) 2659-2666.

[37] Hairsine P.B., Moran C.J., Rose C.W., Recent developments regarding the influence of soil surface characteristics on overland flow and erosion, Aust. J. Soil Res. 30 (1992) 249-64.

[38] Hansen B., Schjonning P., Sibbesen E., Roughness indices for estimation of tilled soil surfaces, Soil Tillage Res. 52 (1999) 103-111.

[39] Hawkins R.H., Interpretation of source-area variability in rainfall-runoff relationships, in: Singh V.P. (Ed.), Rainfall-Runoff relationships, Water Resources Publications, Colorado, 1982, pp. 303-324. 
[40] Helming K., Roth Ch.H., Wolf R., Diestel W., Charaterization of rainfall - microrelief interactions with runoff using parameters derived from digital elevation models (DEMs), Soil Technol. 6 (1993) 273-286.

[41] Helming K., Römkens M.J.M., Prasad S.N., Surface roughness related processes of runoff and soil loss: A flume study, Soil Sci. Soc. Am. J. 62 (1998) 243-250.

[42] Helming K., Römkens M.J.M., Prasad S.N., Roughness and sealing effect on soil loss and infiltration on low slope, in: Blume H.P., Eger H., Fleischhauer E., Hebel A., Reij C., Steiner K.G. (Eds.), Towards sustainable land use, Advances in GeoEcology, Catena Verslag, 1998, Vol. 31, pp. 589-595.

[43] Helming K., Römkens M.J.M., Prasad S.N., Sommer H., Erosional development of small scale drainage networks. in: Hergarten S., Neugebauer H.J. (Eds.), Process Modelling and Landform Evolution, Lecture Notes in earth Sci. 78, Springer Verslag, 1999, pp. 123-145.

[44] Huang C., Bradford J.M., Depressional storage for Markov-Gaussian surfaces, Water Resour. Res. 26 (1990) 2235-2242.

[45] Huang C., Bradford J.M., Applications of a laser scanner to quantify soil microtopography, Soil Sci. Soc. Am. J. 56 (1992) 14-21.

[46] Huang C., White E.G., Thwaite E.G., Bendeli A., A noncontact laser system for measuring soil surface topography, Soil Sci. Soc. Am. J. 52 (1988) 350-355.

[47] Jeschke W., Digital close-range photogrammetry for surface measurement, Int. Arch. Photogramm. Rem. Sens. 28 (1990) 1058-1065.

[48] Jetten V., Boiffin J., De Roo A., Defining monitoring strategies for runoff and erosion studies in agricultural catchments: a simulation approach, Eur. J. of Soil Sci. 47 (1996) 579-592.

[49] Johnson C.B., Mannering J.V., Moldenhauer W.C., Influence of surface roughness and clod size and stability on soil water losses, Soil Sci. Soc. Am. J. 43 (1979) 772-777.

[50] Lawrence D.S.L., Macroscale surface roughness and frictional resistance in overland flow, Earth Surf. Processes and Landforms 22 (1997) 365-382.

[51] Li G., Abrahams A.D., Atkinson J.F., Correction factors in the determination of mean velocity of overland flow, Earth Surf. Processes and Landforms 21 (1996) 509-515.
[52] Linden D.R., Van Doren D.M., Parameters for characterizing tillage-induced soil surface roughness, Soil Sci. Soc. Am. J. 50 (1986) 1560-1565.

[53] Linden D.R., Van Doren D.M., Allmaras R.R., A model of the effects of tillage-induced soil surface roughness on erosion, in: ISTRO 11 th Intern. Conference: Tillage and traffic in crop production, Edinburgh, July 1988, Proc. Vol. 1, 1988, pp. 373-378.

[54] Ludwig B., Boiffin J., Chadoeuf J., Auzet A.V., Hydrological structure and erosion damage caused by concentrated flow in cultivated catchments, Catena 25 (1995) 227-252.

[55] Magunda M.K., Larson W.E., Linden D.R., Nater E.A., Changes in microrelief and their effects on infiltration and erosion during simulated rainfall, Soil Technol. 10 (1997) 57-67.

[56] Mertens S., De invloed van gesteentefragmenten op geulerosie in lemig materiaal: een experimenteel onderzoek, unpublished M.Sc. thesis, Catholic University of Leuven, 1994.

[57] Mitchell J.K., Jones B.A., Jr., Micro-relief surface depression storage: analysis of models to describe the depth-storage function, Water Resour. Bull. 12 (1976) 1205-1222.

[58] Moldenhauer W.C., Influence of rainfall energy on soil loss and infiltration rates: II. Effect of clod size distribution, Soil Sci. Soc. Amer. Proc. 34 (1970) 673-677.

[59] Moran M.S., Vidal A., Troufleau D., Qi J., Clarke T.R., Pinter P.J., Mitchell T.A., Inoué Y., Combining multifrequency microwave and optical data for crop management, Remote Sens. of Environ. 61 (1997) 96-109.

[60] Moore I.D., Foster G.R., Hydraulics of overland flow, in: Anderson M.G., Burt T.P. (Eds.), Process Studies in Hillslope Hydrology, John Wiley, Chicester, 1990, pp. 215-253.

[61] Moore I.D., Larson C.L., Estimating microrelief surface storage from point data, Trans. ASAE 22 (1979) 1073-1077.

[62] Moore I.D., Burch G.J., Mackenzie D.H., Topographic Effects on the Distribution of Surface Soil Water and the Location of Ephemeral Gullies, Trans. ASAE 31 (1988) 1098-1107.

[63] Morgan R.P.C., Quinton J.N., Smith R.E., Govers G., Poesen J.W.A., Auerswald K., Chisci G., Torri D., Styczen M.E., The European Soil Erosion Model (EUROSEM): a dynamic approach for predicting sediment transport from fields and small catchments, 
Earth Surf. Processes and Landforms 23 (1998) 527-544.

[64] Nearing M.A., Norton L.D., Bulgakov D.A., Larionov G.A., West L.T., Dontsova K.M., Hydraulics and erosion in eroding rills, Water Resour. Res. 33 (1997) 865-876.

[65] Ogunlela A., Wilson B.N., Rice C.T., Couger G., Rill network development and analysis under simulated rainfall, Am. Soc. Agric. Eng. Paper no. 89-2112 (1989).

[66] Onstad C.A., Depressional storage on tilled soil surfaces, Trans. ASAE 27 (1984) 729-732.

[67] Onstad C.A., Effect of rainfall on tilled soil properties, Am. Soc. Agric. Eng., paper no. 84-2525 (1984).

[68] Onstad C.A., Wolfe M.L., Larson C.L., Slack D.C., Tilled soil subsidence during repeated wetting, Trans. ASAE 27 (1984) 733-736.

[69] Parsons J.P., Abrahams A.D., Luk S.-H., Hydraulics of interrill overland flow on a semi-arid hillslope, southern Arizona., J. Hydrol. 117 (1990) 255-273.

[70] Parsons A.J., Abrahams A.D., Wainwright J., On determining resistance to interrill overland flow, Water Resour. Res. 30 (1994) 3515-3521.

[71] Parsons A.J., Wainwright J., Abrahams A.D., Runoff and erosion on semi-arid hillslopes, in: Anderson M.G., Brooks S.M. (Eds.), Advances in Hillslope Processes, J. Wiley, Chicester, 1997, pp. 1061-1078.

[72] Phelps H.O., The friction coefficient for shallow flows over a simulated turf surface, Water Resour. Res. 6 (1970) 1220-1226.

[73] Poesen J., Govers G., Gully erosion in the loam belt of Belgium: typology and control measures, in: Boardman J., Foster I.D.L., Dearing J.A. (Eds.), Soil erosion on agricultural land, J. Wiley, Chicester, 1990, pp. 513-530.

[74] Potter K.N., Soil properties effect on random roughness decay by rainfal, Trans. ASAE 33 (1990) 1889-1892.

[75] Rauws G., Laboratory experiments on resistance to overland flow due to composite roughness, J. Hydrol. 103 (1988) 37-52.

[76] Risse L.M., Nearing M.A., Zhang X.C., Variability in Green-Ampt effective hydraulic conductivity under fallow conditions, J. Hydrol. 169 (1995) $1-24$.
[77] Roels J.M., Flow resistance in concentrated overland flow on rough slope surfaces, Earth Surf. Processes and Landforms 9 (1984) 541-551.

[78] Römkens M.J.M., Wang J.Y., Soil roughness changes of tillage systems from rainfall. Am. Soc. Agric. Eng. Paper, no. 85-2048 (1985).

[79] Römkens M.J.M., Wang J.Y., Effect of tillage on surface roughness, Trans. ASAE 29 (1986) 429-433.

[80] Saleh A., Soil roughness measurement: chain method, J. Soil and Water Conserv. 48 (1993) 527-529.

[81] Saleh A., Measuring and predicting ridge-orientation effect on soil surface roughness, Soil Sci. Soc. Am. J. 58 (1994) 1228-1230.

[82] Sano E.E., Heate A.R., Troufleau D., Moran M.S., Vidal A., Relation between ERS-1 synthetic aperture radar data and measurements of surface roughness and moisture content of rocky soils in a semiarid rangeland, Water Resour. Res. 34 (1998) 1491-1498.

[83] Savat J., The hydraulics of sheet flow over a smooth surface and the effect of simulated rainfall, Earth Surf. Process. 2 (1977) 125-140.

[84] Savat J., Resistance to flow in rough supercritical sheet flow, Earth Surf. Process. 5 (1980) 103-122.

[85] Schrader S., Langmaack M., Helming K., Impact of collembola and enchytraeidae on soil surface roughness and properties, Biol. Fertil. Soils 25 (1997) 396-400.

[86] Souchere V., King D., Daroussin J., Papy F., Capillon A., Effects of tillage on runoff directions: consequences on runoff contributing area within agricultural catchments, J. Hydrol. 206 (1998) 256-267.

[87] Steichen J.M., Infiltration and random roughness of a tilled and untilled claypan soil, Soil Tillage Res. 4 (1984) 251-262.

[88] Takken I., Govers G., Ciesiolka C.A.A., Silburn D.M., Loch R.J., Factors influencing the velocity-discharge relationship in rills, in: Summer W., Klaghofer E., Zhang W. (Eds.), Modelling Soil Erosion, Sediment Transport and Closely Related Hydrological Processes, Proc. of Symposium held at Vienna, July 1998, IAHS Publ. no. 249, 1998, pp. 63-70.

[89] Turner A.K., Chanmeesri N., Shallow flow of water through non-submerged vegetation, Agric. Water Manage. 8 (1984) 375-385.

[90] Valentin C., Surface crusting in two alluvial soils of northern Niger, Geoderma 48 (1991) 201-222.

[91] Vandaele K., Poesen J., Spatial and temporal patterns of soil erosion rates in an agricultural catchment, central Belgium, Catena 25 (1995) 213-226. 
[92] Vandaele K., Poesen J., Marques de Silva J.R., Govers G., Desmet P., Assessment of factors controlling ephemeral gully erosion in Southern Portugal and Central Belgium using aerial photographs, Zeitschr. Geomorphologie Neue Folge 41 (1997) 273-287.

[93] Van Wesemael B., Poesen J., de Figueiredo T., Govers G., Effects of rock fragments on soil surface roughness evolution during rainfall, Earth Surf. Processes and Landforms 21 (1996) 399-411.

[94] Vieira S.R., Nielsen D.R, Biggar J.W., Spatial Variability of Field-Measured Infiltration Rate, Soil Sci. Soc. Am. J. 45 (1981) 1040-1048.

[95] Warner W.S., Mapping a three-dimensional soil surface with hand-held $35 \mathrm{~mm}$ photography, Soil Tillage Res. 34 (1995) 187-197.

[96] Weltz A.W., Arslan A.B., Lane L.J., Hydraulic roughness coefficients for native rangelands, J. Irrig. Drainage Eng. 118 (1992) 776-790.
[97] Willgoose G., Bras R.L., Rodriguez-Iturbe I., A coupled channel network growth and hillslope evolution model I. theory, Water Resour. Res. 27 (1991) 1671-1684.

[98] Wilson B.N., Small-scale link characteristics and applications to erosion modeling, Trans. ASAE 36 (1993) 1761-1770.

[99] Yair A., Lavee H., Runoff generative processes and runoff yield form arid mantled slopes, Earth Surf. Process. 1 (1976) 235-247.

[100] Yordanov O.I., Guissard A., Approximate selfaffine model for cultivated soil roughness, Physica A 238 (1997) 49-65.

[101] Zhang W., Cundy T.W., Modeling of twodimensional overland flow, Water Resour. Res. 25 (1989) 2019-2035.

[102] Zobeck T.M., Onstad C.A., Tillage and rainfall effects on random roughness: a review, Soil Tillage Res. 9 (1987) 1-20. 